\title{
PENGARUH PEMBERIAN PAKAN YANG BERBEDA TERHADAP PERTUMBUHAN IKAN KERAPU MACAN (Ephinephelus fuscoguttatus) PADA FASE PENDEDERAN DI KERAMBA JARING APUNG (KJA)
}

\section{(The effect of Different Feed on Growth Growth of Tiger Grouper (Ephinephelus fuscoguttatus) at Nursery Phase Reared in Floating Net)}

\author{
Syamsul Akbar ${ }^{1}$, Marsoedi ${ }^{2}$, Soemarno $^{3}$ dan Endhay Kusnendar ${ }^{4}$ \\ ${ }^{1}$ Mahasiswa S3 Program Doktor Ilmu Perikanan dan Kelautan (FIPK) Unibraw \\ ${ }^{2,3}$ Universitas Brawijaya Malang \\ ${ }^{4}$ Badan LitBang KKP
}

\begin{abstract}
Abstrak
Tujuan penelitian ini adalah untuk menentukan jenis pakan yang tepat untuk pertumbuhan ikan kerapu macan pada fase pendederan di keramba jaring apung (KJA). Keramba jaring apung dengan kerangka balok kayu dan pelampung styrofoam. Keramba jaring apung yang digunakan sebanyak 18 petak dan setiap petak dipasang jaring berbentuk kurungan berukuran $1 \times 1 \times 1$ meter. Ukuran mata jaring mesh size 0,5 inch dan atau disesuaikan dengan ikan uji yaitu panjang 9,2 $\pm 0,002 \mathrm{~cm}$ dan berat 5,7 \pm 0,004 gram. Rancangan penelitian yang digunakan adalah rancangan acak kelompok (RAK) untuk menguji pengaruh dua jenis pakan, pakan pellet dan rucah (ikan tajan), dan dipelihara dalam keramba jaring apung dengan kepadatan 75; 100 dan 125 ekor ekor/m ${ }^{3}$. Hasil penelitian menunjukkan bahwa ikan kerapu macan (Ephinephelus fuscoguttatus) yang diberi pakan pellet, menghasilkan pengaruh jumlah konsumsi pakan yang lebih banyak dibandingkan dengan yang diberi pakan ikan rucah, dengan nilai regresi 0,99 .
\end{abstract}

Kata kunci : kerapu macan, Epinephelus fuscoguttatus, padat tebar, pellet dan ikan rucah 


\begin{abstract}
The objectives of this study was to determine the exact type of feed for growing tiger grouper at nursery phase reared in floating net cages (KJA). Floating net with a frame of wood, and Styrofoam floats. Floating net consists of 18 plots and each plot placed shaped net cages measuring $1 \times 1 \times 1$ meters. Mesh sizes adjusted to fish size of 0.5 inch test. Tiger grouper seed weight to the size of $5.7 \pm 0.004 \mathrm{~g}$ and $9.2 \pm 0.002 \mathrm{~cm}$ in length. The design of the study is a randomized block design (RAK) to examine the influence of two types of feed, the commercial feed and feed trash (tajan fish), and maintained in floating net with 75 ekor/m3 density; 100 and 125 tail ekor/m3 / m3. The results showed that the tiger grouper fish feed pellets consumed more than trash fish feed, with the regression of 0.99
\end{abstract}

Keywords: tiger grouper, Epinephelus fuscoguttatus, stocking density, pellet and trash fish

Budidaya merupakan salah satu upaya untuk meningkatkan produksi dan nilai produksi perikanan, terutama untuk jenisjenis biota bernilai ekonomis penting. Pengembangan usaha budidaya perlu dilakukan untuk biota yang memenuhi kriteria tertentu, antara lain stock atau populasi di alam sudah mengalami penurunan atau mendekati punah, usaha penangkapan dari alam sulit dan mahal, permintaan dari konsumen sangat tinggi dan kesinambungan tergantung dari kondisi alam. Dalam hal ini, ikan kerapu memenuhi kriteria dan mempunyai prospek yang sangat baik untuk dibudidayakan. Kriteria tersebut antara lain: ikan kerapu mempunyai nilai ekonomis yang tinggi, banyak diminati konsumen dan dapat hidup dan tumbuh dengan baik di dalam kondisi budidaya (Chua and Teng, 1980; Abdullah et al., 1987; Setyono, 1993).

Perairan laut Batam secara geografis terdiri dari ratusan pulau kecil, dengan pantai memanjang dan luas, kondisi gelombang yang tidak besar serta kualitas fisika, kimia dan biologi perairan yang sesuai untuk budidaya ikan laut. Beberapa faktor tersebut menjadi acuan strategis dan menguntungkan untuk pengembangan budidaya kerapu macan dengan metode 
keramba jaring apung (Akbar, Materi dan Metode 2008).

Kerapu macan (Ephinephelus

Kebutuhan nutrisi pakan benih fuscoguttatus) sebagai bahan kerapu macan harus memiliki kandungan protein yang tinggi, karena tergolong hewan karnivora. Kebutuhan protein ikan kerapu berkisar $\quad 47,8 \%$ sampai $60 \%$ (Suwirya et al., 2005). Hasil beberapa penelitian dapat dilaporkan bahwa kebutuhan protein untuk juvenil Epinephelus striatus adalah lebih besar 55\% (Ellis et al. 1996); Epinephelus malabaricus $47.8 \%$ (Chen and Tsai, 1994), sementara untuk humpback grouper (Cromileptes altivelis) diperlukan pakan dengan kandungan protein 40-50\% (Giri et al., 1999).

Berdasarkan hasil penelitian tersebut menunjukkan bahwa ikan kerapu macan yang dibudidayakan dalam keramba jaring apung (KJA) mempunyai laju pertumbuhan dan keberhasilan hidup yang baik. Oleh karena itu diperlukan suatu kajian ilmiah mengenai pengaruh pemberian pakan yang berbeda terhadap pertumbuhan ikan kerapu macan (Ephinephelus fuscoguttatus) yang dipelihara dalam keramba jaring apung, sehingga dapat diketahui dengan pasti penyebabnya dan solusi yang harus diterapkan. penelitian ukurannya seragam, dengan berat 5,7 $\pm 0,004$ gram dan pajang 9,2 $\pm 0,002 \mathrm{~cm}$, yang berasal dari hatchery Balai Budidaya Laut Batam. Pendederan kerapu macan menggunakan keramba jaring apung ukuran 1x1x1 meter, dengan kondisi padat penebaran 75 ekor $/ \mathrm{m}^{3} ; 100$ ekor $/ \mathrm{m}^{3}$ dan 125 ekor $/ \mathrm{m}^{3}$. Percobaan dirancang dalam rancangan acak kelompok (RAK) dengan dua perlakuan yaitu A. pakan pellet kandungan protein minimum 50\%; B. pakan ikan rucah (ikan tajan). Masing-masing perlakuan terdiri dari 3 ulangan.

Parameter

pengamatan meliputi pertambahan berat dan panjang, mortalitas, rasio konversi pakan, protein atau energi rasio dan produksi $\left(\mathrm{kg} / \mathrm{m}^{3}\right)$, yang diukur pada setiap setiap 2 minggu sekali. Sementara untuk data penunjang kualitas air pengamatan dilakukan 1 minggu sekali, yang meliputi DO, $\mathrm{pH}$, salinitas, suhu, $\mathrm{NO}_{3}, \mathrm{NO}_{2}$, amoniak dan kecerahan.

\section{Hasil dan Pembahasan}

Berdasarkan uji BNT taraf kepercayaan $5 \%$ menunjukkan bahwa konsumsi pakan ikan pada kondisi padat penebaran 125 ekor/m $\mathrm{m}^{3}$ nilainya lebih tinggi dari 
pada padat penebaran 75 ekor $/ \mathrm{m}^{3}$ dan $100 \quad$ ekor $/ \mathrm{m}^{3}$. Ikan mengkonsumsi makanan pertamatama untuk memenuhi kebutuhan energinya. Kandungan energi dalam pakan berkaitan erat dengan konsumsi pakan. Menurut Robinson et.al. (2001) energi dalam pakan akan mempengaruhi asupan pakan pada ikan yang diberi makan secara ad libitum. Jika energi dalam pakan terlalu tinggi, ikan akan cepat kenyang sehingga menghentikan konsumsi pakannya.

Keberadaan ikan pada suatu perairan sangat tergantung pada ketersediaan makanan yang dibutuhkannya. Makanan adalah salah satu aspek ekologis yang mempunyai peranan penting dalam menentukan besarnya populasi, pertumbuhan dan reproduksi ikan (Nikolsky, 1963). Pemberian pakan pellet sebagai pengganti pakan ikan rucah dalam penelitian ini dapat diaplikasikan untuk budidaya ikan kerapu macan, karena menunjukkan pertumbuhan berat yang baik serta tidak menunjukkan gejala kekurangan nutrien. Selain itu pakan buatan dapat disimpan dalam jangka waktu yang panjang (Sih Yang Sim et al., 2005).

Berdasarkan Gambar 1. menunjukkan bahwa perlakuan pemberian jenis pakan pellet dan ikan rucah, dan dikondisikan pada padat tebar 75 ekor/m $\mathrm{m}^{3} ; 100$ ekor/m ${ }^{3}$ dan 125 ekor $/ \mathrm{m}^{3}$, menghasilkan jumlah pakan yang dikonsumsi berbeda nilainya. Perlakuan terbaik dihasilkan perlakuan jenis pakan pellet dengan nilai regresi 0,99. Artinya ikan yang dikondisikan pada padat tebar 75 ekor $/ \mathrm{m}^{3} ; 100$ ekor $/ \mathrm{m}^{3}$ dan $125 \mathrm{ekor} / \mathrm{m}^{3}$, dan diberikan pakan pellet menghasilkan pengaruh jumlah konsumsi pakan yang lebih banyak dibandingkan dengan yang diberi pakan ikan rucah.

Pemberian pakan buatan dalam bentuk pelet dapat diaplikasikan untuk budidaya ikan kerapu karena menunjukkan pertumbuhan dan efisiensi pakan yang baik serta tidak menunjukkan gejala kekurangan nutrien. Selain itu pakan buatan dapat disimpan dalam jangka waktu yang panjang (Suwirya et al., 2005). 


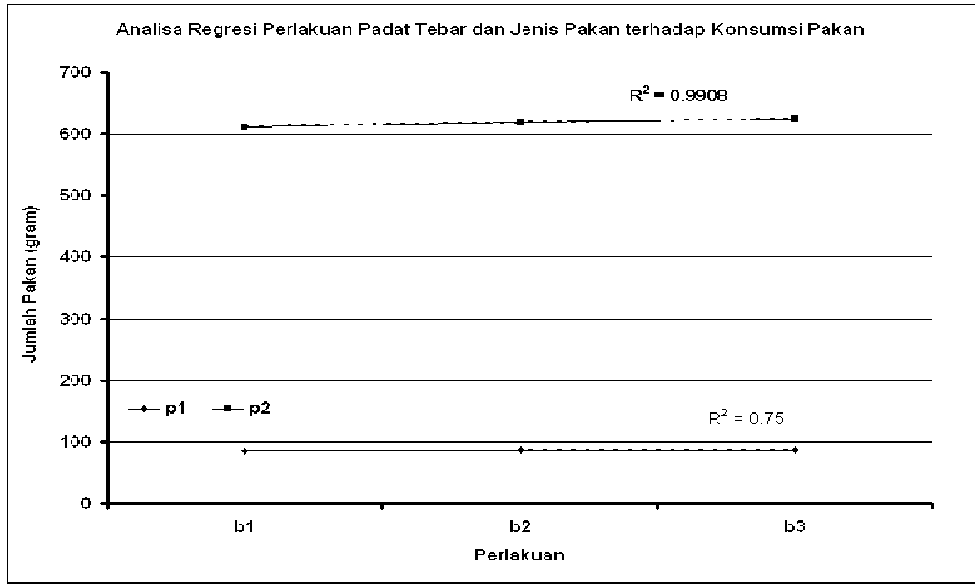

\section{Gambar 1. Analisa regresi perlakuan jenis pakan pellet dan ikan rucah terhadap konsumsi pakan ikan kerapu macan}

Pertumbuhan ikan akan lebih baik jika mendapatkan nutrisi dari pakan tambahan atau buatan. Karena nutrisi yang masuk ke dalam tubuh ikan lebih lengkap dan cukup, (Christiansen and Jobling, 1990). Penggunaan pakan buatan dalam pemeliharaan benih ikan kerapu berpengaruh secara dominan terhadap pertumbuhan ikan karena pakan berfungsi sebagai pemasok energi untuk memacu pertumbuhan dan mempertahan hidupnya (Melianawati dan Suwirya, 2005).

$$
\text { Ahmad et al. (1992), }
$$
berpendapat bahwa pemberian pakan ikan rucah yang berlebihan biasanya akan diikuti dengan proses pembusukan yang memanfaatkan oksigen dari air, yang

mengakibatkan kadar oksigen terlarut menjadi berkurang. Pembusukan bahan organik terutama terdapat pada bahan yang banyak mengandung protein akan menghasilkan ammonium $\left(\mathrm{NH}_{4}\right)$ dan amoniak, bila proses lanjut nitrifikasi tidak berlangsung lancar, maka akan terjadi penumpukan $\mathrm{NH}_{3}$ sampai pada konsentrasi yang membahayakan, yang pada akhirnya mempengaruhi respon ikan terhadap pakan yang diberikan, dengan demikian akan berpengaruh terhadap pertumbuhan.

Komposisi pakan, cara pemberian pakan, waktu pemberian pakan, genetik dan kondisi lingkungan adalah merupakan faktor yang menentukan terhadap 
pertumbuhan ikan dan daya tahan hidup ikan terhadap penyakit dalam suatu sistem akuakultur (Setiawati, 2004).

Efisiensi pakan merupakan jumlah pakan yang masuk dalam sistem pencernaan ikan untuk melangsungkan metabolisme dalam tubuh dan dimanfaatkan untuk pertumbuhan. Efisiensi pakan menunjukkan prosentasi pakan yang diubah menjadi daging atau pertambahan berat, atau perbandingan pertambahan berat ikan dengan jumlah konsumsi pakan.

Efisiensi pakan selama tiga bulan pengamatan berkisar antara 29-40\%. Semakin tinggi nilai efisiensi pakan maka akan semakin optimal dalam meningkatkan pertumbuhan. Secara umum efisiensi pakan yang paling optimal untuk pertumbuhan adalah pada kondisi padat penebaran 75 ekor $/ \mathrm{m}^{3}$. Efisiensi pakan selama 90 hari pengamatan nilai rata-ratanya $34,75 \%$, sementara efisiensi pakan terendah terjadi pada perlakuan padat penebaran $125 \mathrm{ekor} / \mathrm{m}^{3}$. Neltje et al. (2002) dalam penelitian pengaruh pemberian Ronozyme dalam pakan terhadap pertumbuhan ikan kerapu bebek menghasilkan nilai efisiensi pakan sebesar $36,46 \%$, artinya efisiensi pakan dalam penelitian ini masih baik dan sesuai.

Nilai rasio konversi pakan pellet tertinggi terdapat pada padat penebaran 125 ekor $/ \mathrm{m}^{3}$ sebesar 0,85 , sementara nilai rasio konversi pakan pakan rucah tertinggi terdapat pada padat penebaran 125 ekor $/ \mathrm{m}^{3}$ sebesar 6,10. Sih-Yang Sim et al. (2005), menyatakan bahwa nilai rasio konversi pakan pellet untuk kerapu adalah 1,67, sementara untuk FCR pakan rucah adalah 6,0. Pemberian pakan buatan dan ikan rucah pada ikan kerapu bebek selama 4 bulan pemeliharaan menghasilkan nilai rasio konversi pakan masing-masing 1,54 dan 5,82 (Suwirya et al., 2005). Pemeliharaan Yuwana kerapu bebek selama 90 hari dengan pemberian pakan dengan protein $44,30 \%$ menghasilkan nilai rasio konversi pakan terbaik sebesar 3,25 (Agung et al., 2004). Nilai konversi pakan berbeda tergantung jenis pakan, spesies, ukuran ikan, dan suhu perairan (Sunyoto, 1993).

\section{Kesimpulan}

Ikan kerapu macan (Ephinephelus fuscoguttatus) yang diberi pakan pellet, menghasilkan pengaruh jumlah konsumsi pakan yang lebih banyak dibandingkan 
dengan yang diberi pakan ikan rucah, dengan nilai regresi 0,99 .

\section{Saran}

Berdasarkan hasil penelitian tersebut diatas, maka disarankan untuk dilakukan penelitian lanjutan mengenai penerapan pengaruh pemberian pakan pellet dan ikan rucah pada tahap penggelondongan ikan kerapu macan (Ephinephelus fuscoguttatus).

\section{Daftar Pustaka}

Abdullah, M.S., T.O. Wuan and S. Kawahara, 1987. Preliminary

Studies on Stocking Density and Production of Hamoor, Epinephelus tauvina in PVCLined Raceways. Journal of The World Aquaculture Society, Vol. 18. No. 4, pp. 237-241

Agung, A.A., N.A. Giri dan Tridjoko, 2004. Pemeliharaan Kerapu Bebek Cromileptes altivelis dengan Pemberian Pakan Buatan di Tambak. Proseding Seminar Riptek Kelautan Nasional. Hal. 23-26

Ahmad, T., Dewiana dan Suryadi, 1992. Pengaruh Substitusi Tepung Ikan dalam Pakan Terhadap Pertumbuhan Kerapu Lumpur. Journal
Penelitian Budidaya Pantai, 8 (4): Hal. 93-104

Akbar, S. 2008. Status of Trend of Full Cycle Grouper Aquaculture Production and Trade in The Coral Triangle. Country Indonesia. Batam

Chen, H.Y. and Tsai, J.C. 1994. Optimal Dietary Protein Level for The Growth of Juvenile Grouper, Epinephelus malabaricus, Fed Semipurified Diets. Aquaculture 119. p. 265-271

Chua, T.E. and S.K. Teng, 1980. Economic Production of Estuary Grouper, Epinephelus salmoides Maxwell, Reared in Floating Net Cages. Aquaculture, 2, pp. 187-228

Christiansen, J.S. and M. Jobling. 1990. The Behavioural and The Relationships Between Food Intake and Growth of Juvenil Arctic Charr Salvelinus alpinis L. fubjected to sustained exercise. Canadian \ournal of Zoology 68. p. 2185-2191

Ellis, S., G. Viala and W.O. Watanabe. 1996. Growth and Feed Utilisation of HatcheryReared Juvenile of Nassau 
Grouper Fed Four Practical Diets. Prog. Fish. Cult. 58 , p. 167-172

Giri, N.A., K. Suwirya, dan M. Marzuqi, 1999. Kebutuhan Protein, Lemak, dan Vitamin C Yuwana Kerapu bebek, Cromileptes altivelis. Jurnal Penelitian

Perikanan Indonesia, 5(3). Hal. 38-44

Melianawati, R. dan K. Suwirya. 2005. Pengaruh Dosis Pakan terhadap Pertumbuhan Juvenil Kakap Merah. L. Argentimaculatus. Buku Perikanan Budidaya

Berkelanjutan. Hal. 135-142

Neltje, N. Palinggi, Usman, A. Laining, Kamaruddin dan Makmur. 2002. Pengaruh Pemberian Ronozyme $\mathrm{P}$ dalam Pakan Terhadap Pertumbuhan Ikan Kerapu Bebek (Cromileptes altivelis). Balai Riset Perikanan Budidaya Air Payau. Maros. Hal. 1

Nikolsky, G.V. 1963. The Ecology of Fishes. Academic Press. New York

Robinson, E.H., M.H.Lie dan B.B. Manning. 2001. A Practical Guide to Nutrition. Feeds and Feeding of Catfish (2nd.
Rev.). Bulletin 1113. Misissipi Agricultural and Foresty Experiment Station, USA. p. 44

Setiawati, M., 2004. Kebutuhan Nutrient Pakan Peningkat Daya Tahan Tubuh Ikan Dalam Akuakultur. Program Pasca Sarjana S3. Institut Pertanian Bogor Setiadharma, Wardoyo, Setiawati K. M., Giri I.NA., 2002. Efektifitas Padat Tebar Terhadap Sintasan dan Keragaman Benih Kerapu Macan (Epinephelus fuscoguttatus) pada Produksi Secara Masal. Balai Besar Riset Perikanan Budidaya Laut, Gondol. Hal. 1-14

Setyono,

D.E.D.,

1993.

Pertumbuhan, Tingkat Keberhasilan Hidup dan Produksi Bersih Beberapa Ikan Kerapu (Serranidae) yang Dibesarkan di dalam Kurungan Jaring Terapung. Dalam Perairan Maluku dan Sekitarnya, D.P. Praseno, W.S. Atmadja, I. Soepangat, Ruyitno dan B.S. Soedibjo (eds), Balitbang Sumberdaya Laut, Puslitbang Oseanologi, LIPI, Ambon. pp. 69-78 
Sih Yang Sim, M. Rimner, K. William and J.D. Toledo, K. Sugama, I. Rumengan and M.J. Phillips. 2005. Pedoman Praktis Pemberaian dan Pengelolaan Pakan untuk Budidaya Kerapu. Publikasi No. 2005-02 dari Asia-Pacifi c Marine Finfi sh Aquaculture Network. Hal. 1-18

Sunyoto, P. 1993. Pembesaran Kerapu dengan Karamba
Jaring Apung. Penebar Swadaya. Jakarta. Hal. 63

Suwirya, K., N.A. Giri dan M. Marzuqi. 2005. Beberapa Kebutuhan Ikan dalam Pengembangan Pakan untuk Menunjang Budidaya Laut. Prosiding Seminar Riptek Kelautan Nasional. Balai Besar Riset Perikanan Budidaya Laut, Gondol. Bali. Hal. 5 